\title{
Effects of supplemental irrigation on yield and yield attributes of chickpea (Cicer arietinum L.) in Western Ethiopia
}

\author{
Yenus Ousman Kemal ${ }^{1 *}$, Getachew Alemayehu Damot ${ }^{2}$ and Dereje Ayalew Zewudie ${ }^{2}$ \\ ${ }^{1}$ University of Gondar, College of Agriculture and Rural Transformation \\ ${ }^{2}$ Bahir Dar University, College of Agriculture and Environmental Sciences
}

\begin{abstract}
Terminal moisture stress is one of the major factors that reduce the yield of chickpea when it is grown using residual moisture. Field experiment was conducted for two consecutive years (2015/16 and 2016/17) at Teda research site, northwestern Ethiopia to investigate the effect of Supplemental Irrigation (SI) on yield and yield attributes of chickpea (Habru variety). The treatments comprised of six SI levels (no SI/rain-fed, SI at: 50\% flowering, $50 \%$ pod setting; vegetative $+50 \%$ flowering, vegetative $+50 \%$ pod setting stages). The treatments were laid out in randomized complete block design with three replications. Data were analyzed using SAS software, and means were separated by least significant difference test. The result showed that the effect of SI on water use efficiency, yield and most yield components of chickpea such as weight of 100 -seed, biomass yield, number of secondary branch, pods and seeds plant ${ }^{-1}$ was significant. SI generally decreased the water use efficiency of chickpea compared to rain-fed condition. Based on two-year result, SI twice at vegetative + pod setting produced maximum seed yield (30.02 q ha-1), which was at par with that of SI twice at vegetative+ flowering $\left(29.30 \mathrm{q} \mathrm{ha}^{-1}\right)$ and once at vegetative stages $\left(29.17 \mathrm{q} \mathrm{ha}^{-1}\right)$. SI once at vegetative, twice at vegetative + flowering and twice at vegetative + pod setting stages increased seed yield by 12,17 and $19 \%$ in 2015 ; and by 35,24 and $36 \%$ in 2016 , respectively, compared to rain-fed condition. SI once at vegetative stage provided maximum net benefit (45880.40 ETB ha ${ }^{-1}$ ), with a marginal rate of return $(477 \%)$ greater than minimum acceptable level $(100 \%)$. Moreover, it had the highest water use efficiency among SI treatments. Therefore, SI once at vegetative stage can be recommended as the best management option for chickpea production in the study area.
\end{abstract}

Key Words: Supplemental irrigation, chickpea, yield, profit, water use efficiency

DOI: http://dx.doi.org/10.4314/ejst.v11i2.2

\section{INTRODUCTION}

Chickpea can meet its water requirement from residual soil moisture left during the preceding main rainy season. It can withstand drought conditions by extracting water from deeper layers in the soil profile because of its deep tap root system (Gaur et al., 2010). It goes deeper than 150 $\mathrm{cm}$. However, its major water need is extracted from the top $60 \mathrm{~cm}$ of the soil profile, where most of its active roots reside in (Yirga Alemu and Hanibal Lemma, 2012).

Water logging during the main rainy season and terminal moisture stress when chickpea is grown at the end of the season using residual moisture are some of the major obstacles for chickpea production in vertisol areas of Ethiopia. Particularly, water logging leads to crop failure due to root rot (Geletu Bejiga and Yadeta Anbesa, 2002) that in turn impedes chickpea production on

*Corresponding author: ekram.ousman6@gmail.com

(C) This is an Open Access article distributed under the terms of the Creative Commons Attribution License (http://creativecommons.org/licenses/CC BY4.0). 
such type of soil in Ethiopia. To solve this, different researches have been conducted on soil drainage and adjusting of sowing time at the end of the rainy season. For instance Regassa Ayana (2014) recommended sowing at mid-August combined with the use of broad bed and furrows (BBF). Though this and other research results showed promising results, farmers could not benefit from two tmce harvesting from cereal-chickpea double cropping system in a year as the land is left fallow from the beginning to the end of the season when chickpea is commonly grown. So, growing chickpea after harvesting the main cereal crops such as wheat, teff and barley using residual moisture allows farmers to produce second crop in one growing season that in turn boosts crop productivity of scarce land resource and farmers' income (MoA, 2010). However, it is affected by terminal moisture stress when it is grown using residual moisture at the end of the main rainy season. It is often exposed to drought during its active phenological growth stages (Geletu Bejiga and Yadeta Anbesa, 2002; Gaur et al., 2008) that result in poor crop growth and consequently low yield. Drought is among the most serious abiotic constraints to chickpea production. It, together with heat, accounts for about $50 \%$ of the yield losses caused by abiotic stresses (Gaur et al., 2008).

Therefore, alleviating terminal drought through Supplemental Irrigation (SI) to grow chickpea using residual moisture sequentially after cereal crops such as wheat can be helpful to harvest two times in a year, improve crop productivity in the system as a whole and increase the income of farmers. SI results in a substantial improvement in yield and water productivity of the crop (Oweis and Hachum, 2012). Hence, it is one alternative opportunity to increase the productivity of chickpea as it is mostly grown in receding soil moisture, which may not be enough during dry seasons (Menale Kassie et al., 2009). However, mitigation of terminal moisture stress and thereby improving the sustainable productivity of chickpea crop in the study area is scanty. In line with this, research conducted at Dembia district by Yirga Alemu and Hanibal Lemma (2012) highlighted the importance of SI at vegetative stage of chickpea. However, the authors predetermined the amount of irrigation to be $13 \mathrm{~mm}$ at different growth stages without considering the amount of water depleted during each irrigation time, the water holding capacity of the soil, the water requirement of the crop and all the crop data other than grain yield. This indicates the need for further research to consider these gaps. The objective of the experiment was, therefore, to investigate the effects of SI on yield and yield attributes of chickpea.

\section{MATERIALS AND METHODS}

\section{Site Description}

Field experiment was conducted for two consecutive years (2015/16 and 2016/17) in Teda research site of the College of Agriculture and Rural Transformation at the University of Gondar. The site is found in rural areas of Gondar Town Administrative District of Amhara Region, northwestern Ethiopia. It is one of the rural areas surrounding Gondar Town, which is $750 \mathrm{Km}$ from Addis Ababa. The experimental site is located at latitude of $12^{\circ} 28^{\prime} \mathrm{N}$, longitude of $37^{\circ} 29^{\prime} \mathrm{E}$ and has an altitude of 1977 meters above sea level (GPS reading). The average long term (35 years) climate data showed that the study area receives 
a total annual rainfall of $1843 \mathrm{~mm}$. The minimum and maximum temperature was 12.7 and 27.3, respectively. The daily rainfall and reference evapotranspiration (ETo ) pattern for 2015/16 and 2016/17 seasons is depicted in Figure 1. The ET in both years showed similar trend. At sowing time (October), the amount of daily rainfall was higher than daily $\mathrm{ET}_{\mathrm{o}}$ in 2016, but it was lower than the daily $\mathrm{ET}_{\mathrm{o}}$ in 2015. In November (vegetative stage), the rainfall was almost equal to $\mathrm{ET}_{\mathrm{o}}$ in 2015 that could be enough for the crop growth. However, it was zero in the same month and onwards in 2016 (data obtained from Ethiopian Meteorology Agency, Bahir Dar Branch).

\section{Experimental Treatments and Design}

The experimental treatments comprised of six SI levels (no irrigation/rain-fed, irrigation once at: vegetative, $50 \%$ flowering, $50 \%$ pod formation stage; twice irrigation at: vegetative $+50 \%$ flowering stages, vegetative $+50 \%$ pod setting stages). The treatments were laid out in randomized block design (RCBD) with three replications. The experimental area was divided into three blocks, which were further divided in to six plots with the size of $6 \mathrm{~m}^{2}$ ( $2.5 \mathrm{~m}$ long $\times 2.4 \mathrm{~m}$ wide). The spacing between blocks and plots was 2 and $1 \mathrm{~m}$, respectively.

\section{Land Preparation and Sowing}

The land was cropped with wheat during main rainy season. It was plowed two times a week before and at sowing time. Chickpea variety, Habru, was used as a test crop for the experiment. The variety was released by ICARDA (International Center for Agricultural Research in the Dry Areas) in 2004. It is one of the improved Kabuli type chickpeas that are resistant to ascochyta blight, wilt and root rot disease the major disease in the study area. It is largeseeded, fetching almost double the market price of traditional varieties. It can potentially yield up to $4 \mathrm{t} \mathrm{ha}^{-1}$ (ICARDA, 2010). Seeds were sown on October 15, 2015 of the first season and October 20, 2016 of the second year. After preparing the layout and dividing into blocks and plots, seeds were drilled in row planting method on each plot at $40 \mathrm{~cm}$ inter and $10 \mathrm{~cm}$ intra-row spacing.

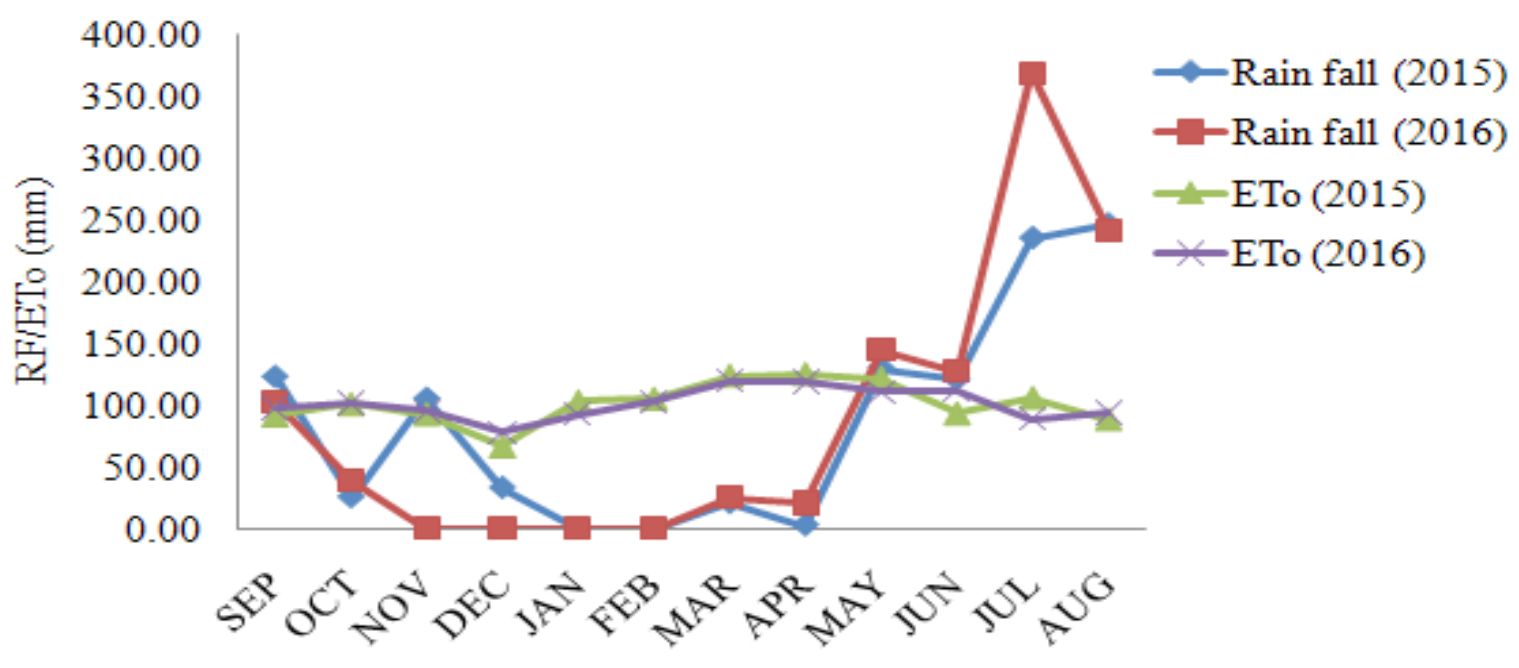

Figure1. Evapotranspiration and rainfall pattern in 2015 and 2016.

Data source: Ethiopian Meteorology Agency, Bahir Dar Branch. 


\section{Crop Management}

Recommended agronomic practices of extension package for the crop, except irrigation treatments, were uniformly followed throughout the growing season. Full dose of blanket recommended chemical fertilizer (100 $\mathrm{kg} \mathrm{ha}^{-1}$ DAP) was applied at sowing time. Weeding was done twice in the growing season. The first weeding was done one month after seed emergence and the second two weeks later. Since boll worm occurred at pod setting stage, Endsulfan 35\% E.C was applied at the rate of 2 liter per hectare.

\section{Soil Sampling and Analysis}

Before land preparation, soil samples were collected diagonally from three spots of the experimental site within 0-30 $\mathrm{cm}$ depth using augur. Soil texture, organic matter content, total $\mathrm{N}$, available $\mathrm{P}, \mathrm{pH}$, electric conductivity (EC) and cation exchange capacity (CEC) were determined in soil laboratory following standard laboratory procedures. Particle size distribution analysis was done by hydrometer method (FAO, 2008). The $\mathrm{pH}$ was determined using 1:2.5 soil to water ratio using a glass electrode attached to a digital $\mathrm{pH}$ meter (FAO, 2008). Soil organic carbon was determined by volumetric method (Walkley and Black, 1934). Organic matter content was calculated as OM (\%) $=\mathrm{OC}^{*} 1.72$. Total nitrogen was analyzed by MicroKjeldhal digestion method using sulphuric acid (Jackson, 1962) while available phosphorus was determined using a spectrophotometer (Olsen et al., 1954).

\section{Soil Moisture Determination and Application of Irrigation Water}

Undisturbed soil samples were taken at 0-30 and
$30-60 \mathrm{~cm}$ depths using core sampler to determine bulk density (BD), moisture content at permanent wilting point (PWP) and field capacity (FC) of the soil just before land preparation. The moisture content at permanent wilting point and field capacity were measured by pressure plate in laboratory. According to the treatments, soil water content was determined gravimetrically at the time of planting (initial moisture content), vegetative, $50 \%$ flowering, and pod setting stages. Soil samples were taken using auger while fresh mass of the soil sample was measured and then ovendried at $105^{\circ} \mathrm{C}$ to constant weight. The dry soil was weighed again using sensitive balance. The moisture content on dry mass basis was calculated (Michael, 1997) as:

Soil moisture content on mass basis

$(\mathrm{w} / \mathrm{w} \%)=\underline{\mathrm{M}}_{\frac{\mathrm{w}}{\mathrm{M}_{\mathrm{d}}}-\mathrm{M}_{\mathrm{d}}} \times 100$

Where, $M_{w}=$ Mass of wet soil sample, $M_{d}=$ mass of dry soil sample

The amount of depleted soil moisture content that was to be refilled back to field capacity was calculated using the following formula.

$d=\sum \frac{\left(M_{f c i}-M_{b i}\right) * A_{i} * D_{i}}{100}$

Where, $\mathrm{d}=$ depth of water to be applied during irrigation (cm), $M_{\mathrm{fci}}=$ moisture content (\%) at field capacity in the $\mathrm{i}^{\text {th }}$ layer of the soil, $\mathrm{M}_{\mathrm{bi}}=$ moisture content (\%) before irrigation in the $i^{\text {th }}$ layer of the soil,

$A_{i}=$ bulk density of the soil $\left(\mathrm{g} \mathrm{cm}^{-3}\right)$ in the $i^{\text {th }}$ layer of the soil and $\mathrm{D}_{\mathrm{i}}=$ depth of the $\mathrm{i}^{\text {th }}$ soil layer within the root zone $(\mathrm{cm})$.

The depth of water to be irrigated at each irrigation 
time (Table 2) was converted to volume of water in litter which was calculated as:

$\mathrm{V}($ liter $)=\mathrm{A} * \mathrm{~d} * 1000$

Where, $\mathrm{V}=$ volume of water to be applied, $\mathrm{A}=$ area of the plot $\left(6 \mathrm{~m}^{2}\right)$ and $\mathrm{d}=$ depth of application (m) Post planting irrigation was applied at vegetative, flowering and pod filling stages according to the treatments as indicated in Table 2, but no irrigation was applied to the control plots (rain-fed condition). The calculated volume of water was applied to each furrow of the treated plots using watering can during each irrigation time as per the treatments. The volume of water applied for each furrow was determined by dividing the volume of water to be applied on the plot with the number of plant rows. The water use efficiency $\left(\mathrm{Kg} \mathrm{m}^{-3}\right)$ was calculated as the ratio of grain yield to seasonal water use (Singh et al. 2016).

\section{Data Collection}

At maturity, five plants were randomly tagged from each net plot area to record data on growth parameters (plant height, number of primary and secondary branches per plant) and yield component parameters (100-seed weight, number of pods per plant and seeds per plant) (Singh et al., 2016). The total values of measured or counted parameters were divided by five to record the average values per plant. Grain and biomass yields were recorded by harvesting the net plot area of $2.76 \mathrm{~m}^{2}(1.2 \mathrm{~m}$ x $2.3 \mathrm{~m}$ ). After harvesting, the total biomass yield was measured using balance, and it was threshed on a mat. Then seed yield of each plot was weighed using sensitive balance and recorded. The seed moisture content was adjusted to $13 \%$, and the yield was converted to quintal ha- ${ }^{-1}$.

\section{Economic Analysis}

To evaluate the economic feasibility of supplemental irrigation, partial economic analysis was done following partial budget analysis as described by CIMMYT (1988). The prevailing market prices of inputs and monetary value of crop products during cropping season were used for analysis. The total variable costs (TVC), gross benefit and net benefit were calculated. Total variable cost was calculated as the sum of cost of fuel and labor for irrigation pumping and cost of irrigation water. The net benefit was calculated as the difference between gross benefit and total costs that vary (TVC). Grain yield was adjusted downwards by $10 \%$ assuming that farmers may obtain yields $10 \%$ lower than those recorded by research results in small plots. The Marginal Rate of Return (MRR) was calculated as the ratio of additional benefits to additional costs between pair of treatments. The MRR was used to assess the relative profitability among alternative treatments. Then treatments were listed according to increase in total costs that vary. The dominance analysis was performed and the dominated treatments were eliminated. A treatment that has net benefits less than or equal to the treatments with lower costs that vary is dominated. A treatment which was non-dominated, having MRR of greater or equal to $100 \%$ and highest net benefit was considered as economically profitable (CIMMYT, 1988).

\section{Statistical Analysis}

All the relevant data collected from the experimental plots were subjected to analysis of variance (ANOVA) using the SAS statistical computer software program ver. 9.1.3 (SAS, 2004). When the treatment effects were significant, means were separated following least significant difference (LSD) test (Gomez and Gomez, 1984). 


\section{RESULTS AND DISCUSSION}

\section{Soil Physical and Chemical Properties of the Experimental Site}

The soil analysis indicated that the experimental farm was clay soil. It had $\mathrm{pH}$ of $7.95,0.21 \mathrm{mS} / \mathrm{cm}$ EC, $57.50 \mathrm{cmol} / \mathrm{kg}$ CEC, $1.15 \%$ OM, $0.06 \%$ total $\mathrm{N}$ and $5.97 \mathrm{ppm}$ available phosphorus. It had bulk density of 1.21 and $1.23 \mathrm{gm} \mathrm{cm}^{-3}$ and 45.70 and $45.70 \%$ porosity within $0-30$ and $30-60 \mathrm{~cm}$ soil depth, respectively. the maximum water holding capacity of soil within effective root zone of chickpea (60 cm soil depth) was $95 \mathrm{~mm}$.

\section{Soil Moisture Depletion Trend and Consumptive Use during the Experimental Periods}

The initial soil moisture content at sowing time was $91 \%$ and $97 \%$ of AWC in 2015 and 2016, respectively. During each irrigation time (vegetative, flowering and pod formation stages), the depleted amount of water was refilled to bring the moisture content to field capacity according to the treatments. Hence, the amount of net irrigation water applied at each irrigation time was equal to

Table1. Physical and chemical properties of soil in the experimental site

Physical properties

\begin{tabular}{|c|c|c|c|c|c|c|c|c|c|}
\hline $\begin{array}{l}\text { Soil depth } \\
(\mathrm{cm})\end{array}$ & $\begin{array}{l}\text { Sand } \\
(\%)\end{array}$ & $\begin{array}{l}\text { Silt } \\
(\%)\end{array}$ & $\begin{array}{l}\text { Clay } \\
(\%)\end{array}$ & $\begin{array}{l}\text { Tex. } \\
\text { Class }\end{array}$ & $\begin{array}{l}\mathrm{BD} \\
\left(\mathrm{gm} \mathrm{cm}^{-3}\right)\end{array}$ & $\begin{array}{l}\mathrm{FC} \\
(\mathrm{mm})\end{array}$ & $\begin{array}{l}\text { PWP } \\
(\mathrm{mm})\end{array}$ & $\begin{array}{l}\text { AWC } \\
(\mathrm{mm})\end{array}$ & $\begin{array}{l}\text { Porosity } \\
(\%)\end{array}$ \\
\hline $0-30$ & 27.28 & 31.28 & 41.44 & Cay & 1.21 & 132.90 & 85.60 & 47.30 & 45.70 \\
\hline $30-60$ & 25.00 & 30.00 & 45.00 & Cay & 1.23 & 133.90 & 86.20 & 47.70 & 46.40 \\
\hline \multicolumn{10}{|c|}{ Chemical properties } \\
\hline $\begin{array}{l}\text { Soil depth } \\
(\mathrm{cm})\end{array}$ & $\begin{array}{l}\mathrm{EC}(\mathrm{mS} / \\
\mathrm{cm})\end{array}$ & $\begin{array}{l}\text { CEC } \\
(\mathrm{cmol} / \mathrm{kg})\end{array}$ & & $\mathrm{pH}$ & OM (\%) & $\begin{array}{l}\text { Total N } \\
(\%)\end{array}$ & $\begin{array}{l}\text { Av. P } \\
(\mathrm{ppm})\end{array}$ & & \\
\hline $0-30$ & 0.21 & 57.30 & & 7.95 & 1.15 & 0.06 & 5.97 & & \\
\hline
\end{tabular}

The moisture content at field capacity and wilting point was 132.90 and $85.60 \mathrm{~mm}$ within $0-30$ $\mathrm{cm}$ and 133.90 and $86.20 \mathrm{~mm}$ within $30-60 \mathrm{~cm}$, respectively. The total Available Water Content (AWC) within 0-30 and 30-60 cm soil depth was 47.30 and $47.70 \mathrm{~mm}$, respectively (Table1). Hence, the depleted soil moisture content (Table 2). The amount of depleted moisture content at vegetative, flowering and pod setting stages was 25,67 , and 73 $\mathrm{mm}$ in 2015; and 30, 70 and $75 \mathrm{~mm}$ in 2016, respectively in plots treated with one time irrigation treatments. 
Table 2. Amount of Supplemental Irrigation (SI), Effective Rainfall (ER) and Seasonal Water Use (SWU) of chickpea at different crop growth stages

\begin{tabular}{|c|c|c|c|c|c|c|}
\hline \multirow{2}{*}{$\begin{array}{l}\text { Treatments } \\
\text { Vegetative }\end{array}$} & \multicolumn{3}{|c|}{ SI at Crop growth stages } & \multirow{2}{*}{$\begin{array}{l}\text { Total SI } \\
(\mathrm{mm})^{*}\end{array}$} & \multirow{2}{*}{$\begin{array}{l}\text { ERF } \\
(\mathrm{mm})\end{array}$} & \multirow{2}{*}{$\begin{array}{l}\text { SWU } \\
(\mathrm{mm})\end{array}$} \\
\hline & Flowering & & $\begin{array}{l}\text { Pod } \\
\text { setting }\end{array}$ & & & \\
\hline \multicolumn{7}{|l|}{ First season (2015) } \\
\hline Non SI/rain-fed & 0.00 & 0.00 & 0.00 & 0.00 & 45.00 & 45.00 \\
\hline SI once vegetative (V) & 25.00 & 0.00 & 0.00 & 25.00 & 45.00 & 70.00 \\
\hline SI once at flowering $(\mathrm{F})$ & 0.00 & 67.00 & 0.00 & 67.00 & 45.00 & 112.00 \\
\hline SI once at pod setting $(\mathrm{P})$ & 0.00 & 0.00 & 73.00 & 73.00 & 45.00 & 118.00 \\
\hline SI twice at $\mathrm{V}+\mathrm{F}$ & 25.00 & 44.00 & 0.00 & 69.00 & 45.00 & 114.00 \\
\hline SI twice at $\mathrm{V}+\mathrm{P}$ & 25.00 & 0.00 & 51.00 & 76.00 & 45.00 & 121.00 \\
\hline \multicolumn{7}{|l|}{ Second season (2016) } \\
\hline Non SI/rain-fed & 0.00 & 0.00 & 0.00 & 0.00 & 53.00 & 53.00 \\
\hline SI once vegetative (V) & 30.00 & 0.00 & 0.00 & 30.00 & 53.00 & 83.00 \\
\hline SI once at flowering $(\mathrm{F})$ & 0.00 & 70.00 & 0.00 & 70.00 & 53.00 & 123.00 \\
\hline SI once at pod setting $(\mathrm{P})$ & 0.00 & 0.00 & 75.00 & 75.00 & 53.00 & 128.00 \\
\hline SI twice at $\mathrm{V}+\mathrm{F}$ & 30.00 & 50.00 & 0.00 & 80.00 & 53.00 & 133.00 \\
\hline SI twice at $\mathrm{V}+\mathrm{P}$ & 30.00 & 0.00 & 52.00 & 82.00 & 53.00 & 135.00 \\
\hline
\end{tabular}

$*=$ the amount of water in $\mathrm{mm}$ is within effective root zone depth of chickpea $(60 \mathrm{~cm})$

The amount of depleted moisture content, which was refilled to field capacity during vegetative stage, was again depleted to 44 and $50 \mathrm{~mm}$ at flowering and 51 and $52 \mathrm{~mm}$ at pod setting stages in 2015 and 2016 in plots treated with twice irrigation at vegetative + flowering and vegetative + pod setting, respectively (Table 2). Total seasonal consumptive use in chickpea crop growth was 45 and $53 \mathrm{~mm}$ for rain-fed condition. It was 70 and 83, 112 and 123, and 128 and $118 \mathrm{~mm}$ for one time irrigation at vegetative, flowering, pod setting, while for twice irrigation at vegetative + flowering and vegetative + pod setting was 114 and $133 \mathrm{~mm}$, and 121 and $135 \mathrm{~mm}$ in 2015/16 and 2016/17 growing season, respectively. Generally, the seasonal consumptive use was higher in 2016/17 than in 2015/16 season. This could be because the second season is drier than the first one, which is congruent with what has been stated by Ray et al. (2011) regarding seasonal variation in moisture depletion trend and seasonal water use of chickpea.

\section{Plant Height}

The analysis of variance showed that the effect of SI on plant height was not significant during 2015 , while it was highly $(\mathrm{p}<0.01)$ significant effect in 2016 (Table 3). The non-significant effect 
of SI in the first year might be due to relatively higher rainfall during vegetative stages of the crop (Figure1). In the second year, significantly the longest plants $(47.97 \mathrm{~cm})$ were recorded due to twice SI at vegetative + flowering, followed by one time irrigation at vegetative stage, while the shortest plants $(43.17 \mathrm{~cm})$ were observed from non-irrigated plots. It could be attributed to the sufficient moisture available in root zone of chickpea which can increase the nutrients availability to plant that increased the vegetative growth and leaves that in turn help to manufacture more food material with the presence of chlorophyll. In line with the present result, some research results indicated non-significant effect of SI on plant height (Abdurazzak et al., 2014; Nawab et al., 2015; Singh et al., 2016), but others (Singh, 2017; Yagmur and Kaydan, 2011) reported significant effect of SI on plant height.

Table 3. Effects of SI on plant height and weight of 100 -seeds

\begin{tabular}{lllllll}
\hline \multirow{2}{*}{ Treatments } & \multicolumn{3}{l}{ Plant height } & \multicolumn{3}{l}{ Weight of 100 seeds } \\
\cline { 2 - 7 } & 2015 & 2016 & Mean & 2015 & 2016 & Mean \\
\hline No SI/rain-fed & 45.67 & $43.17^{\mathrm{c}}$ & 44.42 & $30.14^{\mathrm{c}}$ & $30.13^{\mathrm{c}}$ & $30.24^{\mathrm{d}}$ \\
SI at Vegetative (V) & 45.43 & $46.87^{\mathrm{ab}}$ & 46.15 & $30.44^{\mathrm{bc}}$ & $31.63^{\mathrm{b}}$ & $31.56^{\mathrm{ab}}$ \\
SI at flowering (F) & 44.60 & $44.30^{\mathrm{c}}$ & 44.45 & $30.47^{\mathrm{bc}}$ & $31.33^{\mathrm{b}}$ & $30.90^{\mathrm{cd}}$ \\
SI at Pod forming (P) & 42.47 & $44.13^{\mathrm{c}}$ & 43.30 & $30.50^{\mathrm{bc}}$ & $31.33^{\mathrm{b}}$ & $31.08^{\mathrm{bc}}$ \\
SI at V+F & 44.00 & $47.97^{\mathrm{a}}$ & 45.98 & $31.64^{\mathrm{a}}$ & $32.67^{\mathrm{a}}$ & $32.15^{\mathrm{a}}$ \\
SI at V+P & 44.33 & $46.00^{\mathrm{b}}$ & 45.17 & $31.13^{\mathrm{ab}}$ & $32.67^{\mathrm{a}}$ & $31.72^{\mathrm{ab}}$ \\
F-test & $\mathrm{ns}$ & $* *$ & $\mathrm{~ns}$ & $*$ & $*$ & $*$ \\
LSD (P $<0.05)$ & & 1.30 & & 0.75 & 1.20 & 0.73 \\
CV $(\%)$ & 7.39 & 1.58 & 6.09 & 1.35 & 2.15 & 2.00 \\
\hline
\end{tabular}

ns $=$ non significant, $*=$ significant, $* *=$ highly significant, letters followed by the same letter are not significant.

\section{Number of Primary and Secondary Branches}

As shown in Table 4, SI had no significant effect on primary branches in both years. During the first season, SI had also no significant effect on secondary branch. On the other hand, effect of treatments on secondary branch was significant ( $p$ $<0.05)$ in the second season. The non-significant response of the number of branches to SI in 2015 might be due to relatively higher rainfall during vegetative growth stages of the crop (Figure 1). Based on two year mean result, twice irrigation at vegetative + flowering stages produced significantly maximum number of branches (8.82), which was statistically at par with treatments of one time irrigation at vegetative (8.37) and twice irrigation at vegetative + pod forming stages (8.40). The non-irrigated treatments produced the fewest branches. This might be due to reduction of cell division and enlargement under water shortage. 
Table 4. Effects of SI on number of primary and secondary branches

\begin{tabular}{lllllll}
\hline & $\begin{array}{l}\text { number } \\
\text { plant }\end{array}$ & & of & primary & branch & \multicolumn{2}{c}{$\begin{array}{l}\text { number of secondary branch } \\
\text { plant }^{-1}\end{array}$} \\
\cline { 2 - 7 } Treatments & 2015 & 2016 & Mean & 2015 & 2016 & Mean \\
\hline No SI/rain-fed & 2.13 & 2.22 & 2.18 & 7.80 & $7.00^{\mathrm{c}}$ & $7.40^{\mathrm{b}}$ \\
SI at Vegetative (V) & 2.13 & 2.17 & 2.15 & 8.33 & $8.40^{\mathrm{ab}}$ & $8.37^{\mathrm{ab}}$ \\
SI at flowering (F) & 2.13 & 2.17 & 2.15 & 7.67 & $7.27^{\mathrm{bc}}$ & $7.47^{\mathrm{b}}$ \\
SI at Pod forming (P) & 2.32 & 2.27 & 2.29 & 7.73 & $7.73^{\mathrm{bc}}$ & $7.73^{\mathrm{b}}$ \\
SI at V+F & 2.27 & 2.33 & 2.30 & 8.47 & $9.17^{\mathrm{a}}$ & $8.82^{\mathrm{a}}$ \\
SI at V+P & 2.27 & 2.18 & 2.22 & 8.73 & $8.07^{\mathrm{ab}}$ & $8.40^{\mathrm{ab}}$ \\
F-test & $\mathrm{ns}$ & $\mathrm{ns}$ & $\mathrm{ns}$ & $\mathrm{ns}$ & $*$ & $*$ \\
LSD (P<0.05) & & & & & 1.26 & 1.08 \\
CV $(\%)$ & 6.23 & 12.71 & 8.88 & 11.28 & 8.75 & 11.34 \\
\hline
\end{tabular}

ns $=$ non significant, $*=$ significant, $* *=$ highly significant, letters followed by the same letter are not significant.

The significant effect of the second year result agrees with the finding of previous research results reported by Yagmur and Kaydan (2011), Abdurazzak et al. (2014) and Shamsi et al. (2010) who observed significant effect of SI on number of branches. Particularly Shamsi et al. (2010) found maximum number of branches with one-time irrigation at pod-filling stage, i.e. 58.1\% higher than the value obtained from rain-fed condition. On the other hand, the non-significant effect in the first season agrees with such other results as Nawab et al. (2015), Singh et al. (2016) who reported nonsignificant effect of SI on number of branches.

\section{Weight of 100-Seeds}

The effect of SI on weight of 100-seeds was significant $(\mathrm{p}<0.05)$ in two-year study (Table 3$)$. In both years, the heaviest seeds were produced by supplementing with twice irrigation at vegetative + flowering stages, which was at par with twice irrigation at vegetative + pod setting and onetime irrigation at vegetative stage. The result agrees with previous findings on chickpea (Shamsi et al., 2010; Ouji et al., 2016; Singh et al., 2016) who reported significant improvement of 100 -seed weight due to supplemental irrigation. The improvement of 100seed weight was obtained due to SI at flowering + pod formation stages (Ouji et al., 2016) or with one-time irrigation at pod-filling stage (Shamsi et al., 2010), while the minimum values were recorded from non-irrigated plots. Singh et al. (2016) also reported that weight of 100-seeds with irrigation at vegetative/early flowering phase significantly increased, and it was further increased by additional irrigation at the pod forming stage in the first season of the two-year study. However, Rasaei et al. (2012) found non-significant effect of SI on100-grain weight.

\section{Number of Pods and Seeds}

Analysis of variance revealed that the effect of SI on number of pods and seeds per plant was significant $(\mathrm{p}<0.05)$ in both years. Significantly higher number of pods and of seeds per plant 
was recorded on plots treated with irrigation at vegetative, vegetative + flowering or vegetative + pod filling. Based on the two-year mean result, the maximum number of pods (34.75) and of seeds (36.52) was recorded with twice irrigation at vegetative + pod setting, which was at par with that of one time irrigation at vegetative and twice irrigation at vegetative + flowering. The fewest pods (28.66) and seeds (29.01) were produced in rain-fed condition (Table 5). The increment is attributed to the sufficient soil moisture in the root zone that increased the number of primary and secondary branches, which ultimately increased the number of pods and seeds (Singh, 2017).

The observation is consistent with other results (Rasaei et al., 2012; Shamsi et al., 2010; Silva et al., 2014; Singh et al., 2016; Singh, 2017; Yagmur and Kaydan, 2011). Significant improvement of pod number per plant was found due to two-time irrigation at branching and pod formation (Ray et al., 2011). One-time irrigation at 50\% flowering or pod-filling also increased the number of seeds by $188 \%$ (Shamsi et al., 2010). According to Singh et al. (2016), the number of pods plant ${ }^{-1}$ increased by double irrigation in the first season and by single irrigation at flowering or pod formation in the second season. Singh (2017) also reported that the number of pods/plant of chickpea significantly increased with the application of two-time irrigation at pre-flowering + grain filling stage. However, Nawab et al. (2015) reported insignificant effect of irrigation on number of pods and seeds per plant.

Table 5. Main effects of SI on number of pods and seeds

\begin{tabular}{lllllll}
\hline \multirow{2}{*}{ Treatments } & \multicolumn{3}{c}{ Number of pod plant $^{-1}$} & \multicolumn{3}{c}{ Number of seed plant $^{-1}$} \\
\cline { 2 - 7 } & 2015 & 2016 & Mean & 2015 & 2016 & Mean \\
\hline No SI/rain-fed & $28.47^{\mathrm{c}}$ & $28.84^{\mathrm{c}}$ & $28.66^{\mathrm{c}}$ & $28.80^{\mathrm{c}}$ & $29.36^{\mathrm{c}}$ & $29.01^{\mathrm{d}}$ \\
SI at Vegetative (V) & $32.49^{\mathrm{ab}}$ & $35.92^{\mathrm{a}}$ & $34.20^{\mathrm{ab}}$ & $33.79^{\mathrm{ab}}$ & $38.13^{\mathrm{ab}}$ & $35.56^{\mathrm{a}}$ \\
SI at flowering (F) & $28.99^{\mathrm{bc}}$ & $30.87^{\mathrm{c}}$ & $29.93^{\mathrm{c}}$ & $30.27^{\mathrm{bc}}$ & $34.77^{\mathrm{bc}}$ & $31.25^{\mathrm{cd}}$ \\
SI at Pod forming (P) & $31.28^{\mathrm{abc}}$ & $31.52^{\mathrm{bc}}$ & $31.38^{\mathrm{bc}}$ & $32.10^{\mathrm{abc}}$ & $34.36^{\mathrm{ac}}$ & $32.23^{\mathrm{bc}}$ \\
SI at V+F & $34.54^{\mathrm{a}}$ & $32.84^{\mathrm{ab}}$ & $33.88^{\mathrm{ab}}$ & $35.42^{\mathrm{a}}$ & $39.32^{\mathrm{ab}}$ & $34.55^{\mathrm{ab}}$ \\
SI at V+P & $34.07^{\mathrm{a}}$ & $35.42^{\mathrm{ab}}$ & $34.75^{\mathrm{a}}$ & $35.87^{\mathrm{a}}$ & $30.34^{\mathrm{a}}$ & $36.52^{\mathrm{a}}$ \\
F-test & $*$ & $*$ & $* *$ & $*$ & $*$ & $* *$ \\
LSD $(\mathrm{P}<0.05)$ & 3.88 & 4.30 & 2.95 & 4.09 & 5.53 & 3.21 \\
\hline
\end{tabular}

$\mathrm{ns}=$ non significant, $*=$ significant, $* *=$ highly significant, letters followed by the same letter are not significant.

\section{Above Ground Biomass}

SI had significant influence $(\mathrm{p}<0.05)$ on biomass yield of chickpea. In the first season, twice irrigation at vegetative along with flowering or pod setting produced significantly maximum biomass yield, which was at par with one-time irrigation at vegetative stage. The non- irrigated treatment produced the lowest value. In the second season, one time irrigation at vegetative stage gave significantly maximum biomass yield. Based on the pooled result, one-time irrigation at vegetative 
stage, twice at vegetative + flowering and vegetative + pod setting increased biomass yield by 43,31 , and $27 \%$, respectively, over the rain-fed condition (Table 6). The present result agrees with the report of other researchers (Shamsi et al., 2010; Rasaei et al., 2012; Silva et al., 2014; Singh et al., 2016; Ouji et al., 2016). That is, biomass yield significantly increased by one time SI at flowering + pod formation stages (Ouji et al., 2016) or onetime irrigation at pod-filling stage (Shamsi et al., 2010) compared to that under rain-fed condition. Singh et al. (2016) also reported that irrigation at the vegetative stage significantly increased biomass yield by $59 \%$ in the first season and by $30 \%$ in the second season compared to biomass yield in un-irrigated plots. Silva et al. (2014) observed maximum biomass yield of chickpea with full $(100 \%)$ crop irrigation requirements, while Rasaei et al. (2012) recorded maximum on pea with SI at flowering and podding. However, Nawabet al. (2015) observed non-significant effect of irrigation on biological yield in Pakistan.

\section{Seed Yield}

The effect of SI on seed yield was significant $(p<0.05)$ in 2015 and highly significant $(p<0.01)$ in 2016 growing season. During the first seasons, significantly maximum grain yield was produced from plots treated with two-time SI at vegetative + flowering $\left(27.22 \mathrm{q} \mathrm{ha}^{-1}\right)$ or vegetative + pod setting $\left(27.53 \mathrm{q} \mathrm{ha}^{-1}\right)$, which was followed by one-time irrigation at vegetative stage $\left(26.01 \mathrm{q} \mathrm{ha} \mathrm{h}^{-1}\right)$. During the second seasons, significantly maximum grain yield was observed from two-time SI vegetative + pod setting (32.50 $\mathrm{q} \mathrm{ha}^{-1}$ ), which was at par with that of one time irrigation at vegetative stage $\left(32.32 \mathrm{q} \mathrm{ha}^{-1}\right)$ and twice at vegetative + flowering (31.36 q ha-1). The lowest yield was observed in rain-fed condition in the two-year study. Compared to rain-fed condition, application of SI twice at vegetative + pod forming, vegetative + flowering and once at vegetative stage increased seed yield by 19,17 , and $12 \%$, respectively, in 2015 and 36,24 , and $35 \%$, respectively, in 2016. Based on the two-year mean result, SI twice at vegetative + pod forming, vegetative + flowering or once at vegetative stage significantly increased seed yield by 27, 24 and 24\%, respectively. However, two-time SI at flowering or pod setting stage did not further improve seed yield compared to SI at vegetative stage (Table 6). Yield improvement of SI at vegetative stage was more pronounced in 2016 than in 2015. This could be because there was no rainfall during vegetative stage in the second year to replenish the crop evapotranspiration demand (Figure1). The non-significant improvement of one-time SI at flowering or pod setting stage might be due to the deep black soil that forms wide cracks during dry season of flowering and pod setting stage so that portions of the irrigation water could easily go down to deeper soil below effective root zone through the cracks as similarly observed in Dembia District of north Gondar by Yirga Alemu and Hanibal Lemma (2012). Therefore, it is important to supplement irrigation at vegetative stage before soil cracks are formed in dry soils to protect water loss through the cracks. The present result goes parallel with other studies (Shamsi et al., 2010; Yagmur and Kaydan, 2011; Rasaei et al., 2012; Silva et al., 2014, Acharya et al., 2015; Singh et al., 2016; Ouji et al., 2016), which stated that irrigation had significant effect on chickpea yield. The use of SI at vegetative, flowering and pod-filling stages is essential for obtaining higher grain yield of chickpea (Acharya et al., 2015). Significantly high yield was found with one-time irrigation at pod-filling (Shamsi et al., 2010) or at vegetative stage followed by irrigation at flowering and at pod-filling stage (Acharya et al., 2015) in 
comparison with that which was found in rainfed condition. Singh et al. (2016) also reported that irrigation at pod-forming stage significantly increased seed yield by $36 \%$ in the first season and irrigation at flowering increased the value by $7 \%$ in the second season compared to the un-irrigated plots. However, the present result disagrees with that of Nawab et al. (2015), who reported that irrigation did not appreciably affect grain yield of chickpea.

There was strong and highly significant positive correlations between grain yield and yield component parameters such as plant height ( $\mathrm{r}$ $=0.60 * *)$, number of secondary branches $(\mathrm{r}=$
$0.76 * *)$, number of pods per plant $(\mathrm{r}=0.73 * *)$, number of seeds per plant $\left(\mathrm{r}=0.76^{* *}\right)$, weight of 100 seeds $\left(r=0.65^{* *}\right)$ and biological yield $(r$ $=0.63 * *)$. The association of these parameters indicated that the vigorous plant growth in terms of taller plants and higher number of branches might lead to production of higher number of pods and seeds, which are heavier. These associations in turn contributed to produce higher grain yield. The positive and significant association results are consistent with the results of Shamsi et al. (2010) and Parveen et al. (1999) who reported high dependence of seed yield on plant height, secondary branches and number of pods per plant.

Table 6. Effect of SI on seed and biomass yield of chickpea

\begin{tabular}{lllllll}
\hline \multirow{2}{*}{ Treatments } & \multicolumn{5}{l}{ Seed Yield } \\
\cline { 2 - 7 } & 2015 & 2016 & Mean & 2015 & 2016 & Mean \\
\hline No SI/rain-fed & $54.60^{\mathrm{b}}$ & $41.13^{\mathrm{c}}$ & $47.79^{\mathrm{c}}$ & $23.22^{\mathrm{c}}$ & $23.93^{\mathrm{b}}$ & $23.58^{\mathrm{b}}$ \\
SI at Vegetative (V) & $59.59^{\mathrm{ab}}$ & $77.24^{\mathrm{a}}$ & $68.42^{\mathrm{a}}$ & $26.01^{\mathrm{ab}}$ & $32.32^{\mathrm{a}}$ & $29.17^{\mathrm{a}}$ \\
SI at flowering (F) & $55.01^{\mathrm{b}}$ & $53.08^{\mathrm{bc}}$ & $54.05^{\mathrm{bc}}$ & $25.33^{\mathrm{abc}}$ & $25.31^{\mathrm{b}}$ & $25.33^{\mathrm{b}}$ \\
SI at Pod forming (P) & $56.24^{\mathrm{b}}$ & $58.34^{\mathrm{b}}$ & $57.29^{\mathrm{b}}$ & $23.81^{\mathrm{bc}}$ & $25.31^{\mathrm{b}}$ & $24.56^{\mathrm{b}}$ \\
SI at V+F & $63.07^{\mathrm{a}}$ & $62.25^{\mathrm{b}}$ & $62.66^{\mathrm{ab}}$ & $27.22^{\mathrm{a}}$ & $31.36^{\mathrm{a}}$ & $29.30^{\mathrm{a}}$ \\
SI at V+P & $62.53^{\mathrm{a}}$ & $59.20^{\mathrm{b}}$ & $60.87^{\mathrm{ab}}$ & $27.53^{\mathrm{a}}$ & $32.50^{\mathrm{a}}$ & $30.02^{\mathrm{a}}$ \\
F-test & $*$ & $*$ & $* *$ & $*$ & $* *$ & $* *$ \\
LSD (P=0.05) & 5.75 & 13.13 & 8.71 & 2.57 & 4.80 & 2.85 \\
CV $(\%)$ & 5.40 & 8.53 & 6.97 & 5.55 & 9.27 & 8.92 \\
\hline
\end{tabular}

$\mathrm{ns}=$ non significant, $*$ = significant, $* *=$ highly significant, letters followed by the same letter are not significant.

\section{Harvest Index}

The effect of SI was not significant in the twoyear results (Table 7). This could be because the increase in grain yield was accompanied by an increase in biomass yield, which maintains the harvest index values non-significant as a result of irrigation treatments as also reported by Silva et al. (2014). On the contrary, Ouji et al. (2016) and Rasaei et al. (2012) found improvement of harvest index due to supplemental irrigation. 


\section{Water Use Efficiency}

The effect of SI on water use efficiency of chickpea was highly significant $(\mathrm{p}<0.01)$ in the two-year study result (Table 8). Based on the two-year mean, the highest water use efficiency (WUE) (5.24 $\mathrm{Kg} \mathrm{m}{ }^{-3}$ ) was recorded from rain-fed treatments followed by one-time irrigation at vegetative stage (4.17 $\mathrm{Kg} \mathrm{m}^{-3}$ ), which gave significantly highest value compared to other SI treatments. It was $68 \%$ efficient in water use compared to two-time irrigation treatments. The result also showed that SI reduced water use efficiency of chickpea compared to rain-fed condition. Similarly, Singh et al. (2016) reported that irrigation of $75 \mathrm{~mm}$ at flowering or at pod setting stage decreased water productivity compared to what may be obtained in rain-fed condition. Sarkar and Sarkar (2017) also observed a decrease in water use efficiency due to irrigation compared to rain-fed condition. On the other hand, Rinaldi et al. (2008) found the best values of water use efficiency by irrigating $50 \mathrm{~mm}$ water once at flowering or at pod filling stage.

Table 7. Effects of SI on harvest index and water use efficiency (WUE)

\begin{tabular}{lllllll}
\hline \multirow{2}{*}{ Treatments } & \multicolumn{5}{l}{ Harvest index } & \multicolumn{5}{l}{ WUE $\left(\mathrm{kg} \mathrm{m}^{-3}\right)$} \\
\cline { 2 - 7 } & 2015 & 2016 & Mean & 2015 & 2016 & Mean \\
\hline No SI/rain-fed & 0.43 & 0.50 & 0.46 & $5.16^{\mathrm{a}}$ & $5.32^{\mathrm{a}}$ & $5.24^{\mathrm{a}}$ \\
SI at Vegetative (V) & 0.44 & 0.52 & 0.48 & $3.72^{\mathrm{b}}$ & $4.62^{\mathrm{b}}$ & $4.17^{\mathrm{b}}$ \\
SI at flowering (F) & 0.46 & 0.45 & 0.46 & $2.26^{\mathrm{c}}$ & $2.26^{\mathrm{c}}$ & $2.26^{\mathrm{c}}$ \\
SI at Pod forming (P) & 0.42 & 0.43 & 0.43 & $2.09^{\mathrm{c}}$ & $2.22^{\mathrm{e}}$ & $2.16^{\mathrm{c}}$ \\
SI at V+F & 0.43 & 0.50 & 0.47 & $2.31^{\mathrm{c}}$ & $2.66^{\mathrm{c}}$ & $2.48^{\mathrm{c}}$ \\
SI at V+P & 0.44 & 0.52 & 0.48 & $2.27^{\mathrm{c}}$ & $2.69^{\mathrm{c}}$ & $2.48^{\mathrm{c}}$ \\
F-test & $\mathrm{ns}$ & $\mathrm{ns}$ & $\mathrm{ns}$ & $* *$ & $* *$ & $* *$ \\
LSD (P<0.05) & & & & 0.31 & 0.64 & 0.35 \\
CV $(\%)$ & 7.32 & 9.35 & 9.22 & 5.68 & 10.67 & 9.50 \\
\hline
\end{tabular}

$\mathrm{ns}=$ non significant, $*=$ significant, $* *=$ highly significant, letters followed by the same letter are not significant.

\section{Partial Economic Analysis}

The dominance analysis indicated that SI once at vegetative stage was dominant, but others were dominated. SI once at vegetative stage gave maximum net benefit of Ethiopian Birr (ETB) 45880.40 with the lowest cost among SI treatments. The MRR of SI at vegetative stage $(731.50 \%)$ is above the minimum acceptable level $(100 \%)$ indicating that the treatments are economically profitable for chickpea production (Table 8). The MRR further implies that if a producer shifts from rain-fed production to SI once at vegetative stage, a profit of ETB 731.50 can be obtained for every additional ETB investment on SI. However, it is not economically feasible to shift from one time SI at vegetative stage to other SI treatments, which have higher production costs but lower net 
benefits. The result indicated that one-time SI at vegetative stage is the most profitable intervention for chickpea production among the tested treatments. The present result is in line with other studies, which recorded the highest net monetary return by irrigation of chickpea at branching and pod development stages (Soma, 2012), two-timeirrigation at pre-flowering + grain filling stage (Singh, 2017) or at irrigation water to cumulative pan evaporation ratio of 0.6 (Sarkar, 2017).

Table 8. Partial economic analysis of SI

\begin{tabular}{lllllll}
\hline Treatments & $\begin{array}{l}\text { GY } \\
\left(\mathrm{Kgha}^{-1}\right)\end{array}$ & $\begin{array}{l}\text { AGY } \\
\left(\mathrm{Kgha}^{-1}\right)\end{array}$ & $\begin{array}{l}\text { NB } \\
(\mathrm{ETB})\end{array}$ & $\begin{array}{l}\text { TVC } \\
(\mathrm{ETB})\end{array}$ & $\begin{array}{l}\text { Dominance } \\
\text { analysis }\end{array}$ & $\begin{array}{l}\text { MRR } \\
(\%)\end{array}$ \\
\hline No SI/rain-fed & 2358.00 & 2122.20 & 38199.60 & 0.00 & - & - \\
SI at Vegetative (V) & 2917.00 & 2625.30 & 45880.40 & 1375.00 & Non D & 731.50 \\
SI at flowering (F) & 2533.00 & 2279.70 & 38234.60 & 2800.00 & D & - \\
SI at Pod forming (P) & 2456.00 & 2210.40 & 36762.20 & 3025.00 & D & - \\
SI at V+F & 2930.00 & 2637.00 & 44441.00 & 3025.00 & D & - \\
SI at V+P & 3002.00 & 2701.80 & 45432.40 & 3200.00 & D & - \\
\hline
\end{tabular}

$\mathrm{GY}=$ grain yield, $\mathrm{AGY}=$ adjusted grain yield, $\mathrm{D}=$ dominated treatment, $\mathrm{TVC}=$ total variable cost, $\mathrm{NB}=$ net benefit, $\mathrm{MRR}=$ marginal rate of return .

\section{CONCLUSION}

From the two-year field experiment, it can be concluded that the effect of SI on yield and most yield attributes of chickpea were significant. Compared to rain-fed condition, application of SI twice at vegetative + pod forming, twice at vegetative + flowering and once at vegetative stage increased seed yield by 27,24 and $24 \%$, respectively. Water use efficiency decreased due to SI treatments. Supplying irrigation once at vegetative stage provided maximum net benefit (45880.40 ETB ha ${ }^{-1}$ ), with MRR (477\%) greater than the minimum acceptable level (100\%) and with the lowest cost. Moreover, it had the highest water use efficiency among SI treatments without significantly decreasing yield. So, SI once at vegetative stage can be recommended as the best management option for chickpea production in the study area.

\section{ACKNOWLEDGEMENTS}

We deeply thank International Plant Nutrient Institute (IPNI) and the University of Gondar for their financial support for field experiment through the principal author. We also extend our gratitude to Mr. Tiwedros from Gondar Agriculture Research Center and Mr. Sisay Ambachew from the University of Gondar for their material support. 


\section{REFERENCES}

Abdu-Razzak, M.D., M.D. Maniruzzaman Bahadur, H.R., Hafiz, P. Bala, A. Haque, Sadat A and Azad A.K (2014). Irrigation levels influenced morpho-physiological characters of chickpea (Cicer arietinum L). International Journal of Agronomy and Agricultural Research 5(4): 6575.

Acharya, N.R., Shrestha, J., Sharma S and Lama G. B. (2015). Study on effect of supplementary irrigation on rain-fed chickpea (Cicer arietinum 1.). International Journal of Applied Science and Biotechnology 3(3): 431-433.

CIMMYT (International Maize and Wheat Improvement Center) (1988). From agronomic data to farmer recommendations: an economics training manual. CIMMYT, Mexico.

FAO (Food and Agriculture Organization of the United Nations) (2008). FAO fertilizer and plant nutrition bulletin: Guide to laboratory establishment for plant nutrient analysis. FAO, Rome, Italy. Pp. 203.

Gaur P.M., Krishnamurthy L and Kashiwagi J. (2008). Improving drought avoidance root traits in chickpea (Cicer arietinum L.): Current status of research at ICRISAT. Plant Production Science 11(1): 3-11.

Gaur P.M., Tripathi S.,, Gowda, C.L.L. G.V., Ranga H.C., Rao, S., Pande S and Sharma M. (2010). Chickpea seed production manual. Andhra Pradesh, India: International crops research institute for the semi-arid tropics. Pp. 28.

Geletu Bejiga and Yadeta Anbesa (2002). Evaluation of Ethiopian chickpea landraces for tolerance to drought. Genetic Resources and Crop Evaluation 49(6): 557-564.

Gomez, K. A and Gomez A. A. (1984). Statistical Procedures for Agricultural Research. Second ed. John Wily and Sons, New York.
ICARDA (International Center for Agricultural Research in the Dry Areas) (2010). Ethiopia and ICARDA: Ties that Bind. No. 29. ICARDA, Aleppo, Syria, Pp.20.

Jackson, M. L. (1962). Soil chemical analysis. New Delhi, Prentice Hall of India Pvt. Ltd. Pp.498.

Menale Kassie, Bekele Shiferaw, Solomon Asfaw, Tsedeke Abate, Geoffrey Muricho, Setotaw Ferede, Million Eshete and Kebebew Assefa. (2009). Current situation and future outlooks of chickpea sub-sector in Ethiopia. International crops research institute for the semi-arid tropics (ICRISAT) and Ethiopian institute of agricultural research (EIAR), Nairobi.

Michael, A.M. (1997). Irrigation theory and practices. Indian agricultural research institute. New Delhi, India. Pp 876.

MOA (Ministry of Agriculture) (2010). Crop variety registration. Issue number 13 . Animal and plant regulatory directorate. Addis Ababa, Ethiopia. Pp. 227.

Nawab, K., Kamal T., Rahmatullah, Rab A and Iqbal, M. (2015). Effect of irrigation on chickpea varieties sown on different dates on irrigated fields of Bannu, Khyber Pakhtunkhwa, Pakistan. Journal of Biology, Agriculture and Healthcare 5(11): 37-42.

Olsen, S. R., Cole, C. W., Watanabe, F. S and Dean, L. A. (1954). Estimation of available phosphorous in soils by extraction with sodium bicarbonate. Journal of Soil Science 96 (1): 308-12.

Ouji, A., El-Bok, S., Mouelhi, M., Younes, M. B and Kharrat, M. (2016). Yield and Yield Components of Chickpea (Cicer arietinum L.) as Influenced by Supplemental Irrigation under Semi-arid Region of Tunisia.World Journal of Agricultural Research 4(5): 153-157.

Oweis, T and Hachum, A. (2012). Supplemental irrigation: a highly efficient water-use practice. 
International center for agricultural research in the dry areas (ICARDA). Aleppo, Syria. Pp. 28.

Parveen, R., Sadiq, M and Saleem, M. (1999). Role of rhizobium inoculation in chickpea under water stress condition. Pakistan Journal of Biological Science 2(2): 452-454.

Rasaei, A., Mohammad, E., Ghobadi, G and Ghobadi, M. (2012). Effect of supplemental irrigation and plant density on yield and yield components of peas (Pisum sativum L.) in Kermanshah region. American Eurasian Journal of Agriculture and Environment Science 12(3): 352-357.

Ray, M., Nanda, M. K and Khan, D. K. (2011). Effect of date of sowing and irrigation on seed yield, yield attributes and water use of chickpea ( Cicer arietinum L.) at lower Gangetic plains of west Bengal. Journal of Crop and Weed Science 7(2): 30-32.

Regassa Ayana. (2014). Response of chickpea (Cicer arietinum L.) to land preparation methods and sowing dates on vertisols of southern and southeastern Ethiopia. International Journal of Agricultural of Science and Research (IJASR) 4(5): 17-26.

Sarkar, S and Sarkar, A. (2017). Role of irrigation and mulch in chickpea (Cicer arietinum L.) growth, productivity and moisture extraction pattern in alluvial Zone of West Bengal. Legume research, India.

SAS (Statistical Analysis System) (2004). User's Guide. SAS 9.1.3 ETL Studio: Cary, NC: SAS Institute Inc., USA.

Shamsi K., Kobraee S and Haghparast R. (2010). Drought stress mitigation using supplemental irrigation in rain-fed chickpea (Cicer arietinum L.) varieties in Kermanshah, Iran. African Journal of Biotechnology 9 (27): 4197-4203.

Silva, L. I, Lourenço E. D., Simões, N and Chaves, M. M. (2014). Yield and water productivity of five chickpea varieties under supplemental irrigation in contrasting years. Irrigation Science 32(5): 393-403.

Singh, G., Ram, H., Aggarwal $\mathrm{N}$ and Turner, N. C. (2016). Irrigation of chickpea (Cicer arietinum 1.) Increases yield but not water productivity. Experimental Agriculture 52 (1): $1-13$.

Soma, L.N. (2012). Irrigation management for chickpea. MSc thesis submitted to the Mahatma Phule Krishi Vidyapeeth, Rahuri - 413 722, dist. Ahmednagar, Maharashtra, India.

Walkley, A and Black, I.A. (1934). An examination of the Degtjareff method for determining soil organic matter and a proposed modification of the chromic acid titration method. Soil Science 37(1): 29-38.

Yirga Alemu and Hanibal Lemma. (2012). Evaluation of double cropping and supplementary irrigation of chickpea using drainage water on vertisols at Dembia district in North Gondar. In: Wondmu Bayu (ed.). Proceeding of the 4 th annual regional conference on completed research activities, 4-7 November, 2009. Amhara national research institute, Bahir Dar, Ethiopia.

Yagmur, M and Kaydan, D. (2011). Plant growth and protein ratio of spring sown chickpea with various combinations of Rhizobium inoculation, nitrogen fertilizer and irrigation under rain fed condition. African Journal of Agriculture Resource 6(12): 2648-2654.

Yirga Alemu and Hanibal Lemma (2012). Evaluation of double cropping and supplemental irrigation of chickpea using drainage water on vertisols at Dembia in North Gondar. In: Wondmu Bayu (ed.). Proceeding of the $4^{\text {th }}$ annual regional conference on completed research activities, 4-7 November, 2009. Amhara Agricultural Research Institute, Bahir Dar, Ethiopia. 